\title{
High incidence of respiratory disease in Australian infants despite low rate of maternal cigarette smoking.
}

\section{Original article}

\author{
Authors \& affiliations \\ Lawrence E. K. Gray ${ }^{1,2}$ \\ Anne-Louise Ponsonby ${ }^{3,4}$ \\ Tiffany Xue Lin ${ }^{2}$ \\ Martin O'Hely ${ }^{1,3}$ \\ Fiona Collier ${ }^{1,2,3}$ \\ Sarath Ranganathan ${ }^{3,4,5}$ \\ Peter D. Sly ${ }^{6}$ \\ Angela Pezic ${ }^{3}$ \\ Mimi L. K. Tang $3,4,5$ \\ David Burgner ${ }^{3,4,7}$ \\ Peter Vuillermin ${ }^{1,2,3}$ \\ ${ }^{1}$ Deakin University, School of Medicine, Geelong, Australia \\ ${ }^{2}$ Barwon Health, Geelong, Australia \\ ${ }^{3}$ The Murdoch Children's Research Institute, Melbourne, Australia \\ ${ }^{4}$ Department of Paediatrics, University of Melbourne, Melbourne, Australia \\ ${ }^{5}$ The Royal Children's Hospital, Melbourne, Australia \\ ${ }^{6}$ Child Health Research Centre, University of Queensland, Brisbane, Australia
}

This is the author manuscript accepted for publication and has undergone full peer review but has not been through the copyediting, typesetting, pagination and proofreading process, which may lead to differences between this version and the Version of Record. Please cite this article as doi: 10.1111/jpc.14436

This article is protected by copyright. All rights reserved. 
${ }^{7}$ Department of Paediatrics, Monash University, Melbourne, Australia

\section{Contact address and email}

Professor Peter Vuillermin

Barwon Infant Study

Deakin University

Geelong 3220

peter.vuillermin@deakin.edu.au

\section{Acknowledgements}

The BIS Investigator Group

BIS Investigator Group: Katrina J. Allen, John B. Carlin, Terrence Dwyer, Leonard Harrison and Richard Saffrey,

This article is protected by copyright. All rights reserved. 


\section{Abstract}

Objective

The burden of wheezing illnesses in Australian infants has not been documented since the success of initiatives to reduce maternal cigarette smoking. We aimed to determine the incidence of wheeze and related health care utilisation during the first year of life, among a contemporary Australian birth cohort.

\section{Design}

A birth cohort of 1074 infants was assembled between 2010 and 2013. Parents completed questionnaires periodically. Several non-exclusive infant respiratory disease phenotypes were defined including any wheeze, wheeze with shortness of breath and recurrent wheeze. Skin prick testing was performed to determine atopic wheeze. Healthcare utilisation for respiratory disease was determined from questionnaires and hospital medical records.

\section{Results}

Retention to 1 year was 840/1074 (83\%). The incidence of any wheeze was $51.8 \%$ (95\% confidence interval $(\mathrm{Cl}) 48.3 \%-55.2 \%$ ), wheeze with shortness of breath $20.6 \%$ (95\% Cl 17.9-23.5), recurrent wheeze 19.4\% (95\% Cl 16.8-22.2) and atopic wheeze $6 \%(95 \% \mathrm{Cl} 4.6-7.8)$. Respiratory illness resulted in primary health care utilisation in $82.2 \%(95 \% \mathrm{Cl} 79.3-84.8)$ of participants and hospital presentation in $8.8 \%(95 \% \mathrm{Cl}$ 7.2-10.6). Maternal smoking during pregnancy was uncommon (15.7\%) and was not associated with wheeze or health resource utilisation. Male sex, familial atopy and 
asthma and smaller household size were associated with higher incidence of wheeze.

Conclusions

Incidence of wheezing illness among Australian infants remains high despite relatively low rates of maternal smoking during pregnancy. The majority of the healthcare burden is borne by primary healthcare services. Further research is required to inform novel prevention strategies.

\section{Key words}

Smoking

Infant

Health resources

Asthma

\section{What is already known}

- Wheezing illnesses are common during infancy, with high associated morbidity and health resource burden, and adverse implications for long term respiratory health

- Maternal smoking during pregnancy is an established risk factor for wheezing illnesses in infancy

- Australia has successfully reduced smoking rates among women of child bearing age and tobacco smoke exposure during infancy

This article is protected by copyright. All rights reserved. 


\section{What this paper adds}

- Despite low rates of maternal smoking during pregnancy, infant respiratory disease is highly prevalent, with more than $50 \%$ of infants wheezing in the first year

- Associated health resource utilisation is high, with more than $80 \%$ attending a GP and $9 \%$ attending an emergency department

- Genetic factors such as sex and family history and environmental factors such as household size remain important determinants of infant respiratory disease.

\section{Manuscript}

\section{Introduction}

Early wheeze predisposes to childhood asthma(1) and persisting deficits in lung function(2), posing a significant health and economic burden.(3) Knowledge of wheeze incidence in Australia and New Zealand is primarily based on cohorts assembled in the 1990s.(4-8) The most recent Australian birth cohort, assembled between 2003 and 2004, found wheeze occurred in more than 30\% of children in the first 2 years of life.(9) Lower respiratory infections (LRI), with or without wheeze, are also prevalent in the first year of life. A community-based Australian cohort assembled between 1989-1992 found LRI in 37\% and wheezing LRI in $25 \%$ of participants in the first year of life.(5) In the time since these studies smoking rates have fallen, with the proportion of Australian women who smoked during pregnancy decreasing from $19 \%$ in $2001(10)$ to $13 \%$ in 2012.(11) Maternal smoking during pregnancy is a major risk factor for wheeze in the first year of life, $(12,13)$ however it 
is not known whether the reduction in maternal smoking during pregnancy has been associated with a concordant reduction in infant wheeze.

We aimed to determine the incidence and burden of wheezing illnesses during the first year of life, among a contemporary Australian birth cohort with low antenatal tobacco smoke exposure.

\section{Methods}

\section{Study population and design}

The Barwon Infant Study (BIS) is a birth cohort study ( $n=1074)$ conducted in southeastern Australia.(14) (Supplementary 1) Ethics approval for this study was obtained from the Barwon Health Human Research Ethics committee HREC number 10/24. Mothers were recruited during pregnancy using an unselected sampling frame. The eligibility criteria were: residents of a defined geographical region in the Barwon area of Victoria; at most 32-weeks gestation at the time of enrolment; and planning to give birth at local hospitals. Birth record data and questionnaires administered during pregnancy were used to identify demographic information and exposure to predicted antenatal risk factors including male sex, family history of allergic disease, exposure to tobacco smoke, older siblings, household size, pet ownership, livestock exposure and other factors listed in Table 1. A short questionnaire was completed by those declining participation. Recruitment was completed in June 2013. Postnatal exposure of children to any breastfeeding and any tobacco smoke was determined from questionnaires completed by parents at $1,3,6,9$ and 12 months. 


\section{Measures of wheeze}

Parents completed a validated respiratory questionnaire(15) (Supplementary 2) at 1 , 3, 6, 9 and 12 months (Figure 1). Parents were asked to report any episodes of wheeze occurring since the previous completed review. On each occasion, wheeze was defined for parents as expiratory "breathing that makes a high-pitched whistling or squeaking sound from the chest, not the throat". Among the infants with parent reported wheeze, we also conducted analyses restricted to the following nonexclusive categories: wheeze with shortness of breath (SOB), recurrent wheeze and atopic wheeze. Wheeze with SOB was defined as any episode of parent reported wheeze with associated shortness of breath. Recurrent wheeze was defined as more than one separate episode of parent-reported wheeze in the first year of life. Atopic wheeze was defined as one or more episodes of parent-reported wheeze in the first year of life and allergic sensitisation at 12 months. Allergic sensitisation following SPT was defined as a wheal size of $2 \mathrm{~mm}$ greater than the negative control to the allergen in the presence of a positive histamine control.(16) Allergens tested were cow's milk, raw egg, peanut, cashew, sesame, house dust mite, cat, dog, rye grass and the fungus Alternaria tenuis.

\section{Measures of health resource utilisation}

For any respiratory illness, parents were asked whether a primary healthcare provider (general practitioner) or emergency doctor was seen and if a specific diagnosis made. Primary healthcare records were not examined to corroborate parent report, however available hospital medical records from the child's first year of life were reviewed for documentation of doctor-detected wheeze, salbutamol use and diagnosis. LRI was defined as an illness associated with wheeze or rattly chest and/or evidence of respiratory distress.(17) 


\section{Statistical Analysis}

At 1, 3, 6, 9 and 12-month reviews, parents were asked about symptoms and health resource utilisation since the previous review but were not asked the dates of these events. Based on interview dates, we generated time-to-event curves for wheeze, wheeze with SOB, primary health attendance and emergency presentation for a respiratory condition. Parent-reported data were censored at 420 days to include delayed but completed 12-month reviews. Data from hospital records were censored at 1 year. We adjusted for differences in exposures between the inception cohort and the non-enrolled mothers using the inverse probability weighting method.(18) This reweighting was used to reflect the distribution of known risk factors among those who formed the inception cohort versus those approached but who were not enrolled. The weights were the inverse of the predicted probability of participation obtained after fitting a logistic regression model that included the predicted risk factors (maternal age, socioeconomic status, household size, family history of asthma and family history of eczema). Weighted logarithmic binomial regression models were then fitted to estimate risk ratios $(R R)$ for associations between antenatal exposures and outcomes. Male sex, family history of atopy, older siblings, maternal smoking during pregnancy, pet ownership during pregnancy, livestock ownership during pregnancy, passive tobacco smoke exposure during infancy and any breastfeeding in infancy were included as covariates in the model due to their predicted association with wheeze during the first year of life. Data were analysed using statistical software Stata/SE version 15.1 (Statacorp, TX, USA).

\section{Results}




\section{Characteristics of the cohort}

Cohort assembly and retention throughout the first year is shown in Figure 1. Baseline characteristics of the infants are detailed in Table 1. Males comprised $51.7 \%$ of the cohort. Maternal smoking rates were low, with $15.7 \%$ reporting smoking during pregnancy, while a further $12.6 \%$ of mothers were passively exposed to any environmental tobacco smoke during pregnancy. During the first year, only $5.2 \%$ of infants were exposed to tobacco smoke in the same room, although $15 \%$ of households had one or more smokers. Women who agreed to participate were more likely to have a family history of allergic disease compared with those declining to participate (Table 2).

\section{Wheeze phenotypes}

$51.8 \%$ (95\% confidence interval $(\mathrm{Cl})$ 48.3-55.2) of infants had at least one episode of parent-reported wheeze during the first year of life, $20.6 \%(95 \% \mathrm{Cl} 17.9-23.5)$ had wheeze with associated with shortness of breath, $19.4 \%(95 \% \mathrm{Cl} 16.8-22.2)$ had recurrent wheeze and $6 \%(95 \% \mathrm{Cl} 4.6-7.8)$ had atopic wheeze.

\section{Primary health care utilisation for a respiratory condition}

$82.2 \%(95 \% \mathrm{Cl} 79.3-84.8)$ of infants utilised a primary healthcare provider for a respiratory condition, comprising 1,305 presentations in total. Parents recalled a diagnosis in $1289 / 1305(98.8 \%)$ of cases. The most common recalled diagnoses were "cold"/“common cold" 276/1305 (21.1\%), "viral infection" 255/1305 (19.5\%) or "bronchiolitis" 127/1305 (9.7\%).

\section{Hospital presentations for a respiratory condition}


In the first year of life, $8.8 \%(95 \% \mathrm{Cl} 7.2-10.6)$ of children had at least one respiratory-related hospital presentation, with a total of 114 presentations identified for the cohort. Of these males accounted for 66/114 (57.8\%). The most common diagnoses recorded were "bronchiolitis" 56/114 (49.1\%), "croup" 20/114 (17.5\%) and "viral infection" $13 / 114$ (11.4\%). 72/114 (63.2\%) respiratory-related hospital presentations were recorded as LRI, of which 50/72 (69.4\%) also had wheeze noted. Salbutamol prescription in the emergency department was documented in 9/114 $(0.8 \%)$ respiratory presentations and subsequent improvement in respiratory symptoms was noted in 2 of these infants.

\section{Sex}

Males had a higher incidence of wheeze with SOB (Weighted Risk Ratio (RR) 1.53; 95\% Cl 1.07-2.17; $P=0.018$ ), atopic wheeze (RR 3.52; 95\% Cl 1.81-6.95; $P<0.001$ ) and primary healthcare utilisation (RR $1.11 ; 95 \% \mathrm{Cl} 1.03-1.23 ; P=0.010)$. There was minimal evidence of an association between male sex and increased likelihood of wheeze (RR 1.04; 95\% Cl 0.88-1.23; $P=0.66)$, recurrent wheeze (RR 1.34; 95\% Cl 0.94-1.92; $P=0.10$ ), or presentation to hospital for a respiratory condition (RR 1.15; 95\% Cl 0.69-1.92; $P=0.54$ ) (Table 3). The association between male sex and respiratory health was more apparent from 6 months of age (Figure 2).

\section{Family history of allergic disease}

Infants with a family history of any allergic disease were more likely to present to hospital for a respiratory condition (RR 6.00; 95\% Cl 1.52-23.67; $P=0.010)$. Infants with a first-degree relative with asthma were more likely to develop wheeze (RR 1.34; 95\% Cl 1.14-1.56; $P<0.001$ ), wheeze with SOB (RR 2.10; 95\% Cl 1.50-2.94; $P<0.001)$, recurrent wheeze (RR 1.79; 95\% Cl 1.24-2.59; $P<0.001)$, utilise primary 
healthcare for a respiratory condition (RR 1.09;95\% Cl 1.02-1.18; $P=0.010)$ and present to hospital for a respiratory condition (RR 3.60; 95\% Cl 2.05-6.30; $P<0.001$ ) (Table 3 and Figure 3).

\section{Household size and older siblings}

Increased household size was associated with reduced risk of recurrent wheeze (RR 0.76; $95 \% \mathrm{Cl} 0.61-0.92 ; P=0.011)$. We found weak evidence that infants with older siblings were more likely to develop wheeze (RR 1.17; 95\% Cl 0.99-1.39; $P=0.066)$. (Table 3).

\section{Pet ownership or livestock exposure}

No associations were found between maternal pet ownership or livestock exposure during pregnancy and wheeze phenotypes or health resource utilisation during the first year of life (Table 3). We identified that livestock ownership was associated with reduced atopic wheeze $(\mathrm{RR} 0.15 ; 95 \% \mathrm{Cl} 0.02-1.12 ; P=0.065)$ with a strong magnitude of effect. The borderline significance partly reflects that this is an uncommon exposure.

\section{Smoking, demographic, pregnancy, birth-related factors and breastfeeding}

No association was identified between maternal smoking or passive smoke exposure during pregnancy (Table 3), parental country of birth, parental age, parental education, SEIFA, plurality, gestational age, birth by caesarean section, birth in a government hospital, birthweight or any breastfeeding in the first year of life and 
wheeze phenotypes or health resource utilisation (data not shown). On sensitivity analysis, weighted for retention over the first year, there was no evidence of attrition bias.

\section{Discussion}

We found low rates of antenatal maternal smoking and infant tobacco smoke exposure in our cohort, however this reflects a rapid decline in smoking in Australia in recent years. At the time of participant recruitment, the 2012 Australian Institute of Health and Welfare (AlHW) report had found that $13 \%$ of women who gave birth smoked during pregnancy and since recruitment was completed there has been a further decline to $9.9 \%$ in 2015.(19) Despite reduced tobacco smoke exposure, the incidence of parent-reported wheeze in the first year of life was greater than $50 \%$, higher than observed in previous Australasian studies.(4-6) Thus despite the success of Australia's anti-smoking legislation and public health campaigns $(20,21)$, there is a clear need to identify and address other modifiable risk factors for adverse respiratory health during early life.

The majority of infants with respiratory illness were managed in a primary care setting, with $82.2 \%$ of infants attending a general practitioner. Only $9.6 \%$ of infants with respiratory illness presented to hospital, however a previous study at the main public hospital in the study region found that of all children presenting to hospital, those with respiratory illness were the most likely to be admitted.(22) The study population and location share many characteristics of other large regional centers in southern Australia(14), indicating that respiratory illnesses in infancy remain a significant resource burden and cost for all levels of Australian healthcare.

This article is protected by copyright. All rights reserved. 
We replicated established associations between male sex(23), family history of asthma(24), smaller household size(25) and adverse respiratory health during infancy.(4-6) Increased sibling number was weakly associated with 'any wheeze', consistent with evidence that older siblings are an important source of viral exposures.(26) By contrast, household size was associated with reduced recurrent wheeze, and to some extent, reduced atopic wheeze, consistent with the wellestablished association between larger household size and decreased allergic disease. $(25,27)$ We found no relationship between pet ownership and infant wheeze, where findings from previous studies have been conflicting.(28) We did however find that livestock ownership was associated with reduced atopic wheeze, although only a small proportion of participants owned livestock, limiting statistical power. These results indicate that both genetics and environmental factors associated with microbial exposure remain important determinants of infant respiratory disease. Our inability to replicate associations between either prematurity or low birth weight and subsequent infant wheeze is likely to be due to the small number of premature and/or small birth weight infants within the cohort.

The strengths of this study include the use of an unselected antenatal sampling frame; use of a validated respiratory questionnaire to assess respiratory symptoms; comparison of parent-reported symptoms with the symptoms and signs recorded in hospital medical records and a high retention rate to 1 year. Data collected on nonresponding participants allowed us to account for potential participation bias at inception and attrition bias over the course of the study by the use of a validated inverse probability weighting method.(18) Frequent reviews reduce the potential for recall bias. Limitations include parental report of smoking and tobacco smoke exposure and the assessment of respiratory symptoms by parental report. The 
relatively low prevalence of parent-reported tobacco smoke exposure during pregnancy in our cohort is in keeping with a contemporaneous nationwide estimate of $13 \%$.(19) Nonetheless, in each case there may be a social bias towards underreporting of cigarette smoking, which could potentially obscure an association with wheeze outcomes among offspring. We did not collect specific data on outdoor tobacco smoking, which has been reported to be as high as $26 \%$ in Australian households with dependent children.(29) However, this is unlikely to be the case in our cohort, as only $15 \%$ of households reported having one or more smokers. Reliable assessment of wheeze may be an important unmeasured confounder which may be over or under-reported depending on parental experience and familiarity with infant wheeze.(30) Consistent with this, there was discordance between parent versus doctor assessment of wheeze status among the subgroup presenting to hospital. The detailed description of wheeze provided to parents (Supplementary 2) and frequency of review are likely to have improved the accuracy of parent report.

\section{Conclusion}

In a contemporary Australian birth cohort, with low rates of maternal tobacco smoke exposure during pregnancy, early respiratory disease is common and continues to pose a major health burden. We have replicated associations between known risk factors and wheeze phenotypes, providing a level of construct validity to the measures conducted in this study. Although many illnesses are managed in the primary healthcare setting, hospital presentation with a respiratory illness was higher than reported in previous Australian studies. As exposure to smoking declines, further studies are needed to identify risk factors to explain the persistently high prevalence of early respiratory disease. 


\section{References}

1. Stern DA, Morgan WJ, Wright AL, Guerra S, Martinez FD. Poor airway function in early infancy and lung function by age 22 years: a non-selective longitudinal cohort study. Lancet. 2007;370(9589):758-64.

2. McGeachie MJ, Yates KP, Zhou X, Guo F, Sternberg AL, Van Natta ML, et al. Patterns of Growth and Decline in Lung Function in Persistent Childhood Asthma. The New England journal of medicine. 2016;374(19):1842-52.

This article is protected by copyright. All rights reserved. 
3. De Palma G, Capilla A, Nadal I, Nova E, Pozo T, Varea V, et al. Interplay between human leukocyte antigen genes and the microbial colonization process of the newborn intestine. Current issues in molecular biology. 2010;12(1):1-10.

4. Lowe AJ, Carlin JB, Bennett CM, Hosking CS, Allen KJ, Robertson CF, et al. Paracetamol use in early life and asthma: prospective birth cohort study. BMJ (Clinical research ed). 2010;341:c4616.

5. Oddy WH, Sly PD, de Klerk NH, Landau LI, Kendall GE, Holt PG, et al. Breast feeding and respiratory morbidity in infancy: a birth cohort study. Archives of disease in childhood. 2003;88(3):224-8.

6. Kusel MM, de Klerk NH, Kebadze T, Vohma V, Holt PG, Johnston SL, et al. Early-life respiratory viral infections, atopic sensitization, and risk of subsequent development of persistent asthma. The Journal of allergy and clinical immunology. 2007;119(5):1105-10.

7. Gillespie J, Wickens K, Siebers R, Howden-Chapman P, Town I, Epton M, et al. Endotoxin exposure, wheezing, and rash in infancy in a New Zealand birth cohort. The Journal of allergy and clinical immunology. 2006;118(6):1265-70.

8. Watson PE, McDonald BW. Water and nutrient intake in pregnant New Zealand women: association with wheeze in their infants at 18 months. Asia Pacific journal of clinical nutrition. 2014;23(4):660-70.

9. Marks G, Zinoviev A, Poulos L, Ampon R, Waters AM. Asthma in Australian children: findings from Growing Up in Australia, the Longitudinal Study of Australian Children. [[Internet]]. Australian Centre for Asthma Monitoring; 2009 [Cat no. ACM 17:[Available from: http://www.aihw.gov.au/publication-detail/?id=6442468289.

10. Laws PJ, Sulivan EA. Australia's mothers and babies 2001 [[Internet]]. Canberra: AlHW; 2004 [AIHW Cat. No. PER 25.:[Available from: http://www.aihw.gov.au/publicationdetail/?id=6442467631.

11. Hilder L, Zhichao Z, Parker M, Jahan S, Chambers GM. Australia's mothers and babies 2012: Canberra: AlHW; 2014 [AIHW Cat. No. PER 69.]. Available from: http://www.aihw.gov.au/publication-detail/?id=60129550033.

12. Gilliland FD, Li YF, Peters JM. Effects of maternal smoking during pregnancy and environmental tobacco smoke on asthma and wheezing in children. Am J Respir Crit Care Med. 2001;163(2):429-36.

13. Lannero E, Wickman M, Pershagen G, Nordvall L. Maternal smoking during pregnancy increases the risk of recurrent wheezing during the first years of life (BAMSE). Respiratory research. 2006;7:3.

14. Vuillermin P, Saffery R, Allen KJ, Carlin JB, Tang ML, Ranganathan S, et al. Cohort Profile: The Barwon Infant Study. International journal of epidemiology. 2015;44(4):1148-60.

15. Powell CVE, McNamara P, Solis A, Shaw NJ. A parent completed questionnaire to describe the patterns of wheezing and other respiratory symptoms in infants and preschool children. Archives of disease in childhood. 2002;87(5):376-9.

16. Molloy J, Koplin JJ, Allen KJ, Tang ML, Collier F, Carlin JB, et al. Vitamin D insufficiency in the first 6 months of infancy and challenge-proven IgE-mediated food allergy at 1 year of age: a case-cohort study. Allergy. 2017.

17. Kusel MM, de Klerk NH, Kebadze T, Vohma x, Holt PG, Johnston SL, et al. Early-life 
respiratory viral infections, atopic sensitization, and risk of subsequent development of persistent asthma. J Allergy Clin Immunol. 2007;119(5):1105-10.

18. Little RJA, Rubin DB. Statistical Analysis with Missing Data: Wiley; 2014.

19. AlHW. Australia's mothers and babies. 2015.

20. Scollo M, Younie S, Wakefield M, Freeman J, Icasiano F. Impact of tobacco tax reforms on tobacco prices and tobacco use in Australia. Tobacco Control. 2003;12(suppl 2):ii59-ii66.

21. Miller CL, Hill DJ, Quester PG, Hiller JE. Impact on the Australian Quitline of new graphic cigarette pack warnings including the Quitline number. Tobacco Control. 2009;18(3):235-7.

22. Hardy A, Fuller DG, Forrester M, Anderson KP, Cooper C, Jenner B, et al. Per capita increase in hospital presentations and admissions among children since the 1990s. Journal of paediatrics and child health. 2016;52(10):935-8.

23. Martinez FD, Wright AL, Taussig LM, Holberg CJ, Halonen M, Morgan WJ, et al. Asthma and Wheezing in the First Six Years of Life. New England Journal of Medicine. 1995;332(3):133-8.

24. Grabenhenrich LB, Gough H, Reich A, Eckers N, Zepp F, Nitsche O, et al. Early-life determinants of asthma from birth to age 20 years: a German birth cohort study. The Journal of allergy and clinical immunology. 2014;133(4):979-88.

25. Strachan DP. Hay fever, hygiene, and household size. BMJ (Clinical research ed). 1989;299(6710):1259-60.

26. Cardoso MR, Cousens SN, de Goes Siqueira LF, Alves FM, D'Angelo LA. Crowding: risk factor or protective factor for lower respiratory disease in young children? BMC public health. 2004;4:19.

27. Ponsonby A-L, Couper D, Dwyer T, Carmichael A, Kemp A. Relationship between early life respiratory illness, family size over time, and the development of asthma and hay fever: a seven year follow up study. Thorax. 1999;54(8):664-9.

28. Dick S, Friend A, Dynes K, AlKandari F, Doust E, Cowie H, et al. A systematic review of associations between environmental exposures and development of asthma in children aged up to 9 years. BMJ open. 2014;4(11):e006554.

29. AlHW. National Drug Strategy

Household Survey

detailed report 2013. 2013.

30. Cane RS, Ranganathan SC, McKenzie SA. What do parents of wheezy children understand by "wheeze"? Archives of disease in childhood. 2000;82(4):327-32. 


\section{Tables}

Table 1. Baseline characteristics of infants in inception vs. cohort with complete respiratory outcomes

\begin{tabular}{|c|c|c|}
\hline Characteristic & Inception cohort $(n=1074)$ & $\begin{array}{l}\text { Cohort with complete } \\
\text { respiratory outcomes at } 1 \\
\text { year }(n=840)\end{array}$ \\
\hline \multicolumn{3}{|l|}{ Sex of child: } \\
\hline Male & $555(51.7 \%)$ & $441(52.5 \%)$ \\
\hline Female & $519(48.3 \%)$ & $399(47.5 \%)$ \\
\hline Twin pairs & $10(0.9 \%)$ & $5(1.1 \%)$ \\
\hline \multicolumn{3}{|l|}{ First degree family history of: } \\
\hline Hay fever & $674(62.8 \%)$ & $543(64.6 \%)$ \\
\hline Eczema & $480(44.7 \%)$ & $383(45.6 \%)$ \\
\hline Asthma & $542(50.5 \%)$ & $421(50.1 \%)$ \\
\hline \multicolumn{3}{|l|}{ Maternal country of birth } \\
\hline Australia & $961(88 \%)$ & $755(89.9 \%)$ \\
\hline Other & $110(11.7 \%)$ & $85(10.1 \%)$ \\
\hline Unknown & $3(0.3 \%)$ & $0(0 \%)$ \\
\hline \multicolumn{3}{|l|}{ Paternal country of birth } \\
\hline Australia & $915(85.2 \%)$ & $723(86.1 \%)$ \\
\hline Other & $108(10.1 \%)$ & $80(9.5 \%)$ \\
\hline Unknown & $51(4.8 \%)$ & $37(4.4 \%)$ \\
\hline Maternal age, years (mean \& SD) & $31.3(4.8)$ & $31.8(4.6)$ \\
\hline Paternal age, years (mean \& SD)) & $33.5(5.9)$ & $33.8(5.5)$ \\
\hline \multicolumn{3}{|l|}{ Maternal education } \\
\hline < year 10 of high school & $12(1.1 \%)$ & $6(0.71 \%)$ \\
\hline Year 10 of high school & $80(7.5 \%)$ & $40(4.8 \%)$ \\
\hline Year 12 of high school & $162(15.1 \%)$ & $119(14.2 \%)$ \\
\hline Trade, certificate, diploma & $266(24.8 \%)$ & $208(24.8 \%)$ \\
\hline Bachelor degree & $354(33 \%)$ & $302(36.0 \%)$ \\
\hline Postgraduate degree & $194(18.1 \%)$ & $162(19.3 \%)$ \\
\hline Unknown & $6(.6 \%)$ & $3(0.4 \%)$ \\
\hline \multicolumn{3}{|l|}{ SEIFA } \\
\hline Low & 357 (33.2\%) & $254(30.2 \%)$ \\
\hline
\end{tabular}




\begin{tabular}{|c|c|c|}
\hline $\begin{array}{l}\text { Middle } \\
\text { High } \\
\text { Unknown }\end{array}$ & $\begin{array}{l}353(32.9 \%) \\
351(32.7 \%) \\
13(1.9 \%)\end{array}$ & $\begin{array}{l}281(33.5 \%) \\
295(35.1 \%) \\
10(1.2 \%)\end{array}$ \\
\hline $\begin{array}{l}\text { Number of siblings at home } \\
0 \\
1 \\
2 \\
3 \text { or more } \\
\text { Unknown }\end{array}$ & $\begin{array}{l}450(41.9 \%) \\
382(35.6 \%) \\
184(17.1 \%) \\
55(5.1 \%) \\
3(0.3 \%)\end{array}$ & $\begin{array}{l}353(42.0 \%) \\
298(35.5 \%) \\
144(17.1 \%) \\
45(5.4 \%) \\
0(0.0 \%)\end{array}$ \\
\hline $\begin{array}{l}\text { Antenatal maternal cigarette smoking: } \\
\text { Yes } \\
\text { No } \\
\text { Unknown }\end{array}$ & $\begin{array}{l}169(15.7 \%) \\
892(83.1 \%) \\
13(1.2 \%)\end{array}$ & $\begin{array}{l}105(12.5 \%) \\
726(86.4 \%) \\
9(1.1 \%)\end{array}$ \\
\hline $\begin{array}{l}\text { Passive smoking by mother during preconception or } \\
\text { pregnancy }\end{array}$ & $135(12.6 \%)$ & $88(10.5 \%)$ \\
\hline $\begin{array}{l}\text { Pet ownership during pregnancy } \\
\text { Yes } \\
\text { No } \\
\text { unknown }\end{array}$ & $\begin{array}{l}790(73.6 \%) \\
278(25.9 \%) \\
6(0.6 \%)\end{array}$ & $\begin{array}{l}618(73.6 \%) \\
219(26.1 \%) \\
3(0.4 \%)\end{array}$ \\
\hline $\begin{array}{l}\text { Livestock ownership during pregnancy } \\
\text { Yes } \\
\text { No } \\
\text { Unknown }\end{array}$ & $\begin{array}{l}73(6.8 \%) \\
985(91.7 \%) \\
16(1.5 \%)\end{array}$ & $\begin{array}{l}60(7.1 \%) \\
773(92.0 \%) \\
7(0.8 \%)\end{array}$ \\
\hline $\begin{array}{l}\text { Delivered in a government hospital } \\
\text { Yes } \\
\text { No }\end{array}$ & $\begin{array}{l}780(72.6 \%) \\
294(27.4 \%)\end{array}$ & $\begin{array}{l}592(70.5 \%) \\
248(29.5 \%)\end{array}$ \\
\hline Delivery via Caesarean section & $333(31 \%)$ & $267(31.8 \%)$ \\
\hline $\begin{array}{l}\text { Gestational age at birth: } \\
32 \text { to } 36 \text { completed weeks } \\
37 \text { to } 42 \text { completed weeks } \\
>42 \text { completed weeks }\end{array}$ & $\begin{array}{l}47(4.4 \%) \\
1,027(95.6 \%) \\
0(0.0 \%)\end{array}$ & $\begin{array}{l}34(4.0 \%) \\
806(95.9 \%) \\
0(0.0 \%)\end{array}$ \\
\hline Birthweight in grams (mean \& SD) & $3528(519)$ & $3550(516)$ \\
\hline $\begin{array}{l}\text { Mother smoked during first year of life } \\
\text { Yes }\end{array}$ & $71(6.6 \%)$ & $60(7.1 \%)$ \\
\hline
\end{tabular}




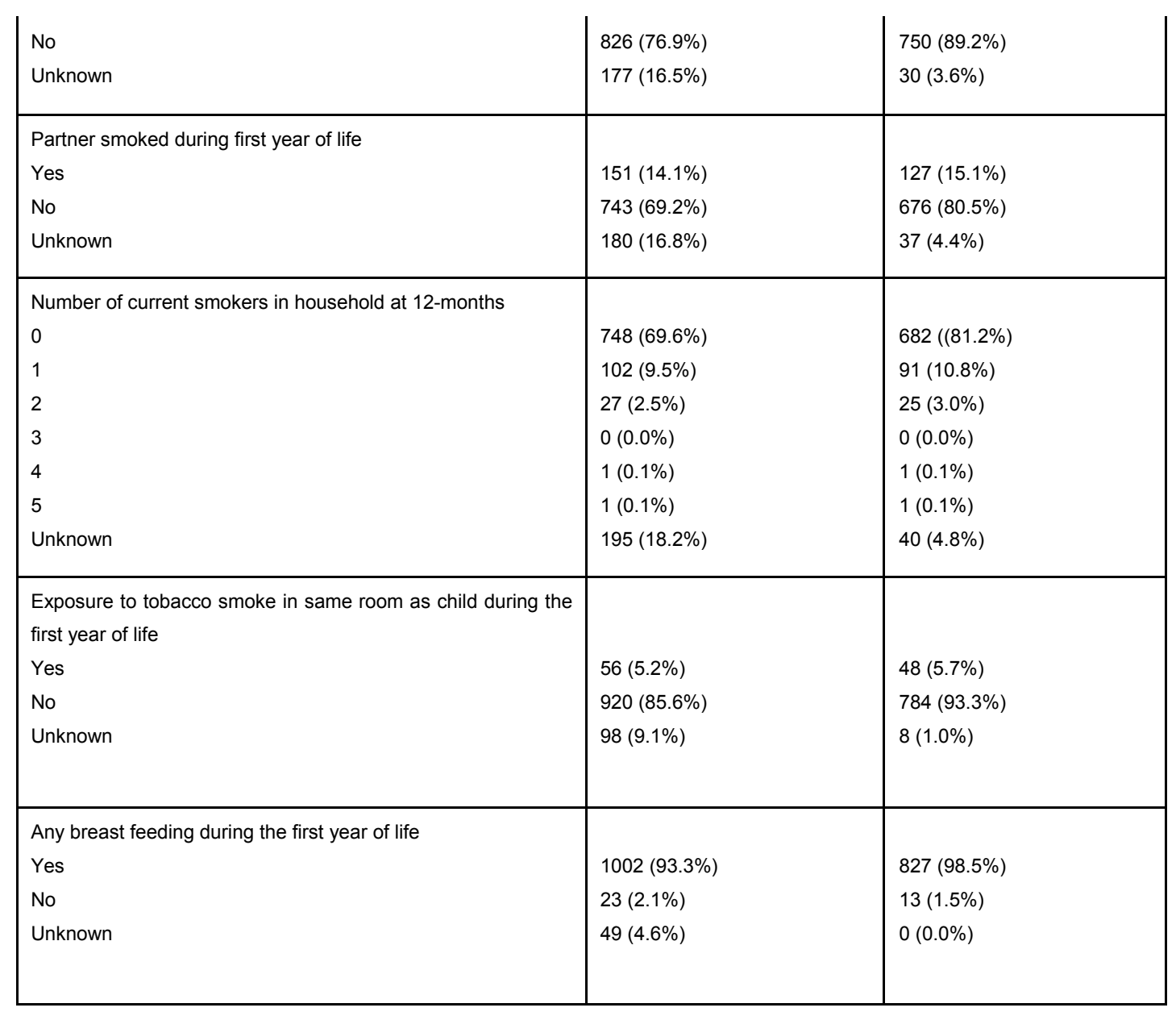


Table 2. Family history of allergic disease in mothers of inception cohort vs. those who declined to participate

\begin{tabular}{|l|l|l|}
\hline $\begin{array}{l}\text { Family history of a first- } \\
\text { degree relative with allergic } \\
\text { disease }\end{array}$ & $\begin{array}{l}\text { Inception } \\
(\mathrm{n}=1064 \text { pregnancies })\end{array}$ & $\begin{array}{l}\text { Non-enrolled mothers } \\
(\mathrm{n}=2869 \text { pregnancies })\end{array}$ \\
\hline Hay fever & $674(63.3 \%)$ & Not recorded \\
\hline Eczema & $480(45.1 \%)$ & $362 / 2094(17.3 \%)$ \\
\hline Asthma & $542(50.9 \%)$ & $506 / 1600(21.6 \%)$ \\
\hline Food allergy & $265(24.9 \%)$ & Not recorded \\
\hline
\end{tabular}

This article is protected by copyright. All rights reserved. 
Table 3. Risk ratios for wheeze phenotypes and health resource utilisation adjusted for male sex, family history of atopy, older siblings, maternal smoking during pregnancy, pet ownership during pregnancy, livestock ownership during pregnancy, passive tobacco smoke exposure during infancy and any breastfeeding in infancy.

\begin{tabular}{|c|c|c|c|c|c|c|}
\hline Characteristic & Wheeze & Wheeze with SOB & Recurrent wheeze & Atopic wheeze & $\begin{array}{l}\text { Primary healthcare } \\
\text { utilisation }\end{array}$ & Hospital presentation \\
\hline Male sex & $\begin{array}{l}1.04 \\
(0.88-1.23)\end{array}$ & $\begin{array}{l}1.53^{*} \\
(1.07-2.17)\end{array}$ & $\begin{array}{l}1.34 \\
(0.94-1.92)\end{array}$ & $\begin{array}{l}3.52^{\star * *} \\
(1.81-6.95)\end{array}$ & $\begin{array}{l}1.11^{*} \\
(1.03-1.23)\end{array}$ & $\begin{array}{l}1.15 \\
(0.69-1.92)\end{array}$ \\
\hline $\begin{array}{l}\text { First degree family history } \\
\text { of allergic disease }\end{array}$ & $\begin{array}{l}1.08 \\
(0.86-1.36)\end{array}$ & $\begin{array}{l}1.62 \\
(0.94-2.80)\end{array}$ & $\begin{array}{l}1.31 \\
(0.75-2.28)\end{array}$ & $\begin{array}{l}1.46 \\
(0.52-4.07)\end{array}$ & $\begin{array}{l}1.07 \\
(0.97-1.18)\end{array}$ & $\begin{array}{l}6.00^{*} \\
(1.52-23.67)\end{array}$ \\
\hline $\begin{array}{l}\text { First degree family history } \\
\text { of asthma }\end{array}$ & $\begin{array}{l}1.34^{\star * *} \\
(1.14-1.56)\end{array}$ & $\begin{array}{l}2.10^{* * *} \\
(1.50-2.94)\end{array}$ & $\begin{array}{l}1.79^{\star *} \\
(1.24-2.59)\end{array}$ & $\begin{array}{l}1.80 \\
(0.92-3.54)\end{array}$ & $\begin{array}{l}1.09^{* *} \\
(1.02-1.18)\end{array}$ & $\begin{array}{l}3.60^{* * *} \\
(2.05-6.30)\end{array}$ \\
\hline Any older siblings & $\begin{array}{l}1.17 \\
(1.00-1.39)\end{array}$ & $\begin{array}{l}1.22 \\
(0.86-1.74)\end{array}$ & $\begin{array}{l}1.22 \\
(0.85-1.74)\end{array}$ & $\begin{array}{l}1.64 \\
(0.80-3.38)\end{array}$ & $\begin{array}{l}0.98 \\
(0.90-1.05)\end{array}$ & $\begin{array}{l}1.00 \\
(0.61-1.67)\end{array}$ \\
\hline $\begin{array}{lll}\text { Household size } & \text { (per } \\
\text { person) } & & \end{array}$ & $\begin{array}{l}1.01 \\
(0.89-1.15)\end{array}$ & $\begin{array}{l}0.98 \\
(0.75-1.27)\end{array}$ & $\begin{array}{l}0.76^{*} \\
(0.61-0.94)\end{array}$ & $\begin{array}{l}0.64 \\
(0.38-1.07)\end{array}$ & $\begin{array}{l}1.01 \\
(0.97-1.05)\end{array}$ & $\begin{array}{l}0.94 \\
(0.60-1.49)\end{array}$ \\
\hline $\begin{array}{l}\text { Pet ownership during } \\
\text { pregnancy }\end{array}$ & $\begin{array}{l}1.06 \\
(0.87-1.29)\end{array}$ & $\begin{array}{l}1.08 \\
(0.72-1.61)\end{array}$ & $\begin{array}{l}1.19 \\
(0.81-1.75)\end{array}$ & $\begin{array}{l}0.81 \\
(0.42-1.55)\end{array}$ & $\begin{array}{l}1.01 \\
(0.92-1.11)\end{array}$ & $\begin{array}{l}0.76 \\
(0.41-1.40)\end{array}$ \\
\hline $\begin{array}{l}\text { Livestock ownership } \\
\text { during pregnancy }\end{array}$ & $\begin{array}{l}0.93 \\
(0.67-1.30)\end{array}$ & $\begin{array}{l}1.08 \\
(0.54-2.17)\end{array}$ & $\begin{array}{l}0.70 \\
(0.37-1.35)\end{array}$ & $\begin{array}{l}0.15 \\
(0.02-1.12)\end{array}$ & $\begin{array}{l}1.07 \\
(0.95-1.21)\end{array}$ & $\begin{array}{l}1.15 \\
(0.30-4.49)\end{array}$ \\
\hline $\begin{array}{l}\text { Antenatal maternal } \\
\text { cigarette smoking }\end{array}$ & $\begin{array}{l}1.00 \\
(0.77-1.31)\end{array}$ & $\begin{array}{l}1.21 \\
(0.73-2.00)\end{array}$ & $\begin{array}{l}1.06 \\
(0.62-1.82)\end{array}$ & $\begin{array}{l}2.21 \\
(0.98-4.93)\end{array}$ & $\begin{array}{l}1.09 \\
(1.01-1.17)\end{array}$ & $\begin{array}{l}1.70 \\
(0.91-3.17)\end{array}$ \\
\hline $\begin{array}{lr}\text { Passive smoking by } \\
\text { mother during } \\
\text { preconception } \\
\text { pregnancy }\end{array}$ & $\begin{array}{l}0.95 \\
(0.65-1.40)\end{array}$ & $\begin{array}{l}0.90 \\
(0.41-1.97)\end{array}$ & $\begin{array}{l}0.49 \\
(0.19-1.24)\end{array}$ & $\begin{array}{l}2.11 \\
(0.88-5.08)\end{array}$ & $\begin{array}{l}1.06 \\
(0.92-1.22)\end{array}$ & $\begin{array}{l}0.39 \\
(0.06-2.59)\end{array}$ \\
\hline
\end{tabular}

Brackets contain 95\% confidence interval

* $\quad P<0.05$

** $\quad P<0.01$

*** $\quad P<0.001$

This article is protected by copyright. All rights reserved. 


\section{Figure legends}

Figure 1. BIS Retention and respiratory response data in the first year of life.

Figure 2. Cumulative incidence of respiratory outcomes separated by sex

Outcomes: Wheeze $=$ Parent reported wheeze; Wheeze with SOB $=$ Parent reported wheeze with shortness of breath; Respiratory HRU = Primary health resource utilisation for a respiratory condition; Respiratory ED presentations $=$ Presentation to hospital for a respiratory condition.

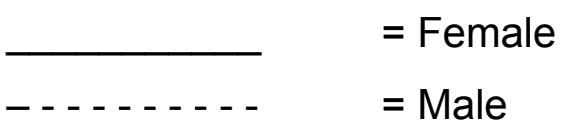

Figure 3. Cumulative incidence of respiratory outcomes separated by family history of first-degree relative with allergic disease.

Outcomes: Wheeze $=$ Parent reported wheeze; Wheeze with SOB $=$ Parent reported wheeze with shortness of breath; Respiratory HRU = Primary health resource

This article is protected by copyright. All rights reserved. 
utilisation for a respiratory condition; Respiratory ED presentations $=$ Presentation to hospital for a respiratory condition.

$=$ No first-degree relatives with allergic disease

$=$ First degree relative(s) with allergic disease

This article is protected by copyright. All rights reserved. 


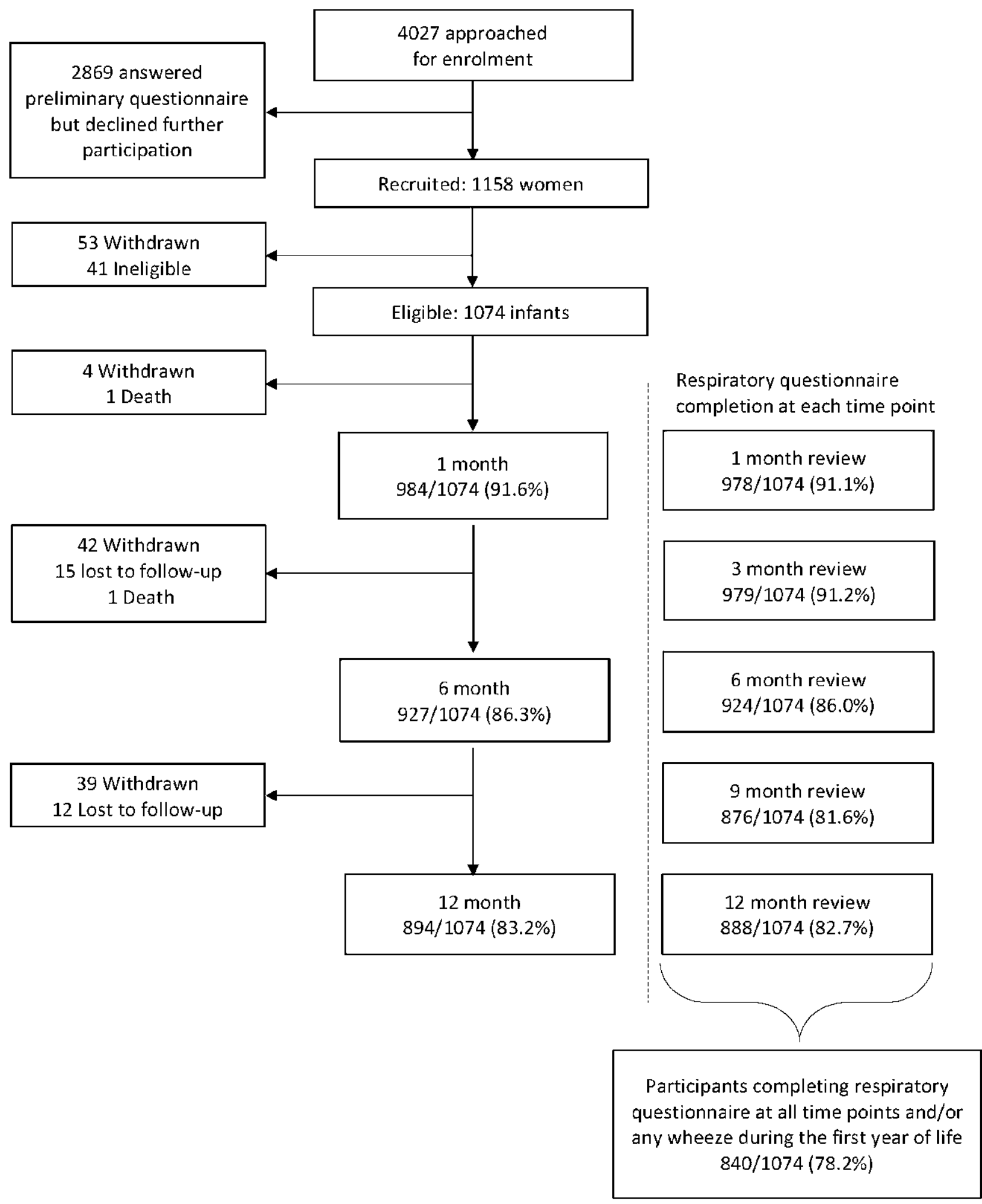

JPC_14436_Figure_1.tiff

This article is protected by copyright. All rights reserved. 

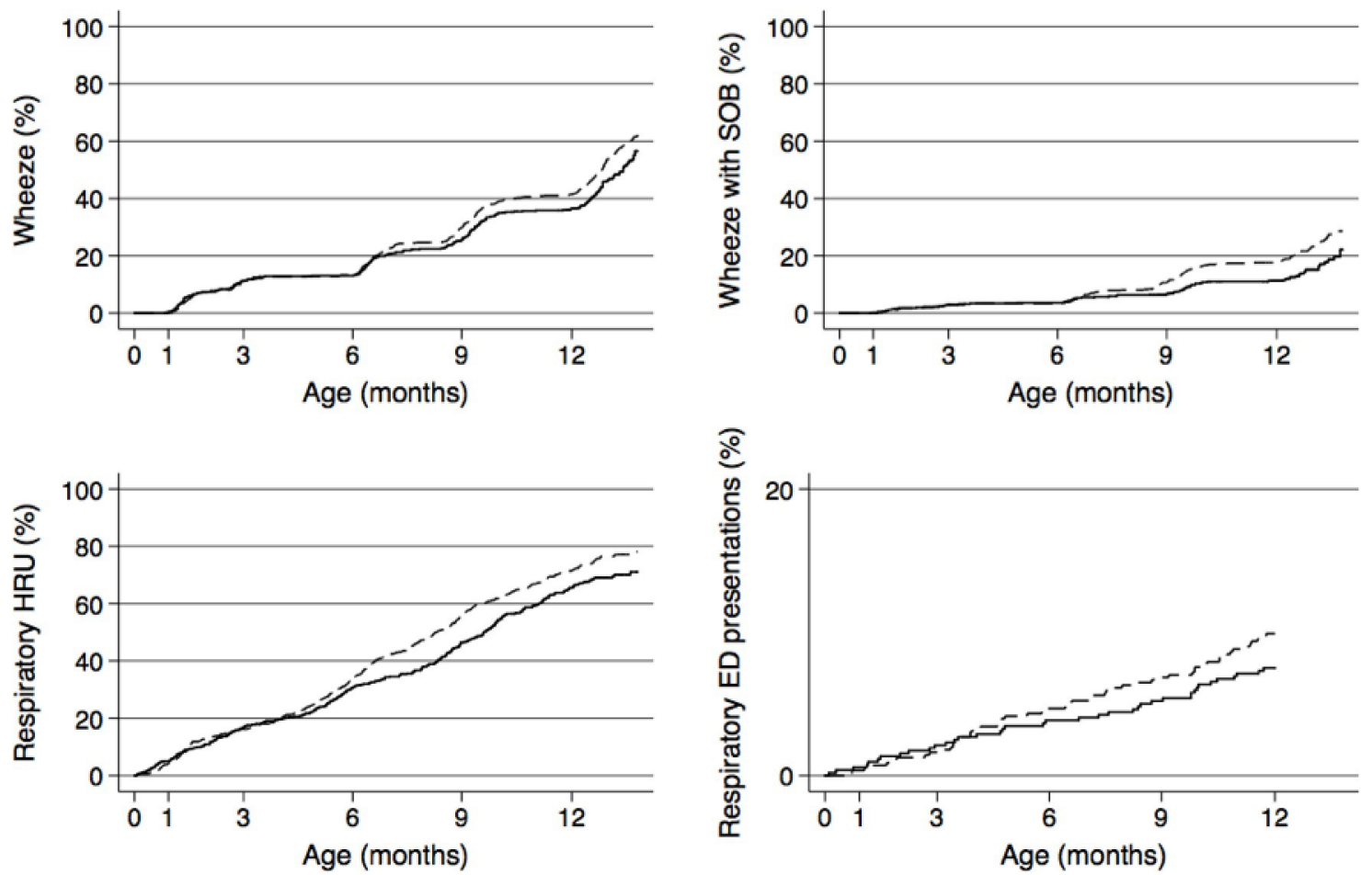

jpc_14436_figure_2.eps

This article is protected by copyright. All rights reserved. 

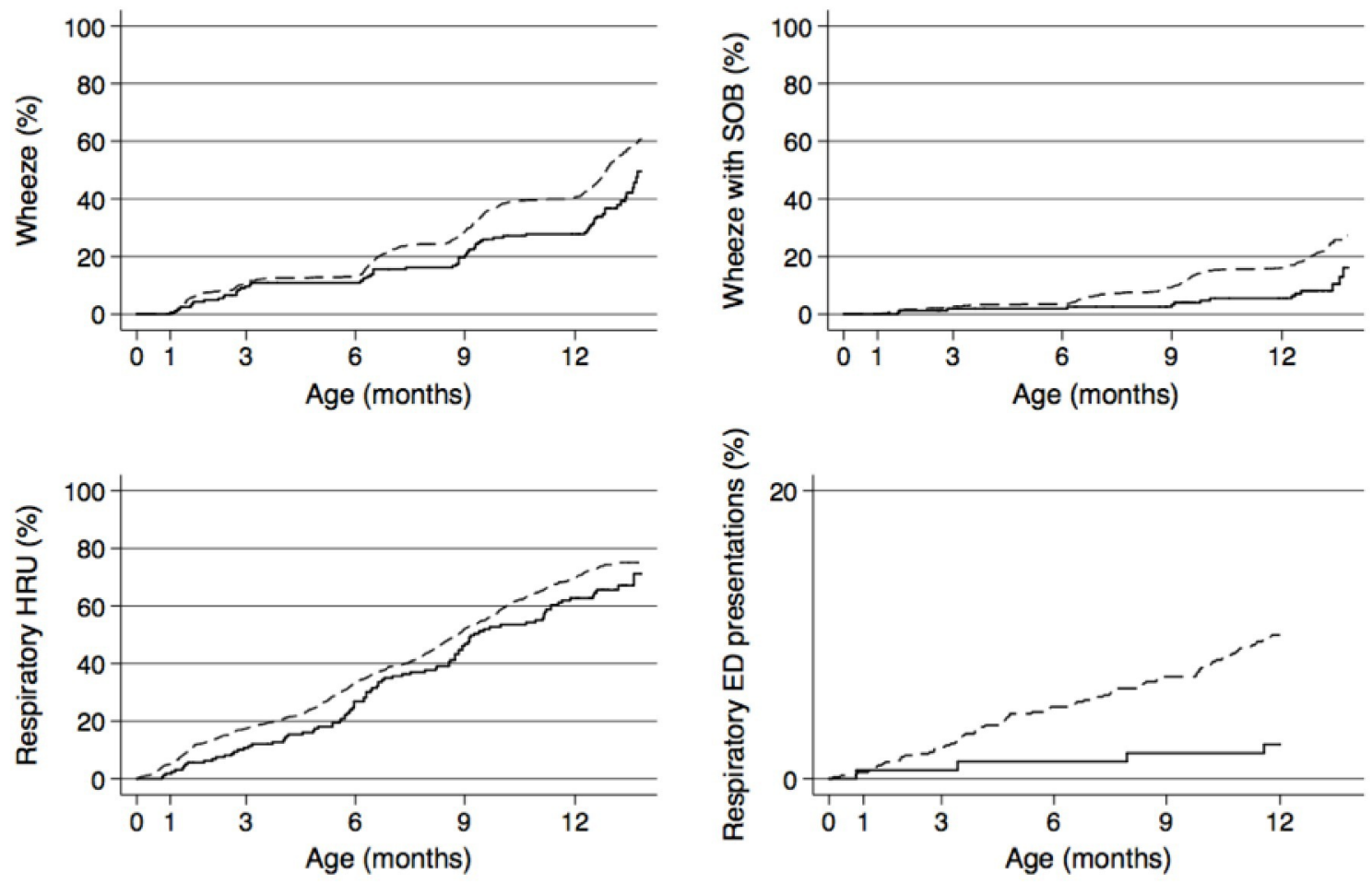

jpc_14436_figure_3.eps

This article is protected by copyright. All rights reserved. 


\title{
High incidence of respiratory disease in Australian infants despite low rate of maternal cigarette smoking.
}

\author{
Original article
}

\author{
Authors \& affiliations \\ Lawrence E. K. Gray ${ }^{1,2}$ \\ Anne-Louise Ponsonby ${ }^{3,4}$ \\ Tiffany Xue Lin ${ }^{2}$ \\ Martin O'Hely ${ }^{1,3}$ \\ Fiona Collier ${ }^{1,2,3}$ \\ Sarath Ranganathan ${ }^{3,4,5}$ \\ Peter D. Sly ${ }^{6}$ \\ Angela Pezic ${ }^{3}$ \\ Mimi L. K. Tang $3,4,5$ \\ David Burgner $3,4,7$ \\ Peter Vuillermin ${ }^{1,2,3}$
}

${ }^{1}$ Deakin University, School of Medicine, Geelong, Australia

${ }^{2}$ Barwon Health, Geelong, Australia

${ }^{3}$ The Murdoch Children's Research Institute, Melbourne, Australia

${ }^{4}$ Department of Paediatrics, University of Melbourne, Melbourne, Australia

${ }^{5}$ The Royal Children's Hospital, Melbourne, Australia

${ }^{6}$ Child Health Research Centre, University of Queensland, Brisbane, Australia

7 Department of Paediatrics, Monash University, Melbourne, Australia

Contact address and email

Professor Peter Vuillermin

Barwon Infant Study

Deakin University 
Geelong 3220

peter.vuillermin@deakin.edu.au

\section{Acknowledgements}

The BIS Investigator Group

BIS Investigator Group: Katrina J. Allen, John B. Carlin, Terrence Dwyer, Leonard Harrison and Richard Saffrey, 


\section{University Library}

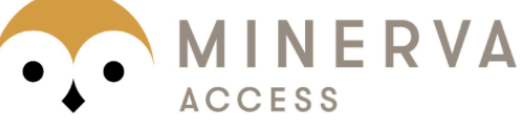

A gateway to Melbourne's research publications

Minerva Access is the Institutional Repository of The University of Melbourne

\section{Author/s:}

Gray, LEK;Ponsonby, A-L;Lin, TX;O'Hely, M;Collier, F;Ranganathan, S;Sly, PD;Pezic, A;Tang, MLK;Burgner, D;Vuillermin, $P$

Title:

High incidence of respiratory disease in Australian infants despite low rate of maternal cigarette smoking

Date:

2019-12-01

Citation:

Gray, L. E. K., Ponsonby, A. -L., Lin, T. X., O'Hely, M., Collier, F., Ranganathan, S., Sly, P. D., Pezic, A., Tang, M. L. K., Burgner, D. \& Vuillermin, P. (2019). High incidence of respiratory disease in Australian infants despite low rate of maternal cigarette smoking. JOURNAL OF PAEDIATRICS AND CHILD HEALTH, 55 (12), pp.1437-1444. https://doi.org/10.1111/ jpc. 14436.

Persistent Link:

http://hdl.handle.net/11343/285793 